\title{
Analysis of the Use of Interactive Research Method Applications
}

\author{
$1^{\text {st }}$ Artha Mahindra Diputera ${ }^{1}, 2^{\text {nd }}$ Roni Sinaga ${ }^{2}, 3^{\text {rd }}$ Aman Simaremare $^{3}$ \\ \{ artha91@unimed.ac.id ${ }^{1}$, ronisinaga@unimed.ac.id ${ }^{2}$, amansimaremare@gmail.com ${ }^{3}$ \} \\ Faculty of Science Education, Universitas Negeri Medan, Medan, Indonesia ${ }^{1,2,3}$,
}

\begin{abstract}
The purposeof the research is to analyze the use of interactive research method applications to support student in preparing their research proposals. The method used is a 10-step development research. The results showed that the application design was declared valid content of 0.83 . Expert assessment is declared reliable based on the ICC value of 0.630 . The readability test got the results of the application getting a score of 159 with readability criteria. The practicality test of using the application found that $79.8 \%$ of respondents agreed that it was in the practical category. The final product in the form of the I-RM Application is distributed through the Play Store. The I-RM application has the advantage that it is practical to use, can store data and compile it into a final project proposal sequence. However, the I-RM application also has drawbacks, namely the data storage is still in local storage, the data cannot be moved or opened via other devices. Suggestions from the researchers are that further development can be carried out to overcome the shortcomings of the currently developed I-RM application and can be tested directly for use in lectures with a longer time span.
\end{abstract}

Keywords: Authentic, assessment; online learning, COVID-19.

\section{Introduction}

Research methodology is one of the compulsory subjects that must be studied in lectures, research methodology is a branch of science that contains methods for conducting observations, searching, compiling and analyzing and concluding data systematically and scientifically [1]. Research can be defined as a systematic investigation to increase the amount of knowledge, it is also a systematic and organized effort to investigate certain problems that require answers.

The research methodology course discusses ways to examine and find a problem in the environment, especially the problem of early childhood education, then examines the problem based on the theory put forward by experts scientifically, formulates steps in finding answers to the problems studied, implements steps Research steps systematically and analyze research results appropriately so that in the end the right answers or conclusions are found to the problems found. Research methodology courses still only use books as learning materials and students are required to be able to prepare proposals as the final project of the course. Research methodology lectures need to be supported by supportive learning tools.

Learning tools are many of materials, tools, media, instructions and guidelines that will be used in the learning process [2, p. 28], Teaching materials are an important part of the learning process [3]. Learning tools in the form of teaching materials began to shift from paper-based 
to digital to facilitate distribution after the Covid-19 pandemic affected lectures at onlinebased universities. Online learning has several impacts on students, namely learning is still confusing for students, students become passive, less creative and productive, accumulation of information/concepts on students is less useful, students experience stress, students' language literacy skills increase [4].

The development of android-based teaching materials has a good impact and influence based on the results of research that has been carried out by several researchers. Mitha (2020) states that $86 \%$ of android-based teaching materials are considered very practical to use [5]. Anggraini, Novianti and Bardadi (2018) researched by developing android-based teaching materials, the results showed that students had $87.5 \%$ pleasure, $90 \%$ interest, $75 \%$ attention, and $80 \%$ involvement in the positive category. Digital-based teaching materials can to improve critical thinking skills [7]. The development of digital-based teaching materials has been supported by rapid educational changes or transformations.

Educational transformation has actually been carried out before the COVID-19 pandemic, as the world is entering the industry 4.0 era which demands high-level thinking skills in data literacy, technological literacy, and human literacy. Android-based learning devices are considered feasible and appropriate in the online learning process, including the Research Methodology course for the Universitas Negeri Medan Early Childhood Education Teacher Education Study Program (PG-PAUD Study Program). The development of android-based learning devices has a good impact and influence based on the results of research that has been carried out by several researchers. Mitha Frilia said that $86 \%$ of android-based teaching materials were considered very practical to use [5]. Anggraini, Novianti and Bardadi conducted research by developing android-based teaching materials, the results showed that students had $87.5 \%$ pleasure, $90 \%$ interest, $75 \%$ attention, and $80 \%$ involvement in the positive category. [6]. Digital-based teaching materials are able to improve critical thinking skills [7]. Based on the explanation of the problem and the results of previous research, it is necessary to conduct research to develop android-based teaching materials for the Research Methodology course.

\section{Methods}

This study uses the development method proposed by Sugiyono, this research goes through stages (1) analysis of potential and problems, (2) data collection, (3) product design, (4) design validation, (5) design revision, (6) test product trial, (7) Product revision, (8) Usage trial, (9) Product revision, (10) Mass production [8][9]. This research was conducted at the Early Childhood Education Study Program, Medan State University. This study involved students who were randomly selected as samples to test the product, the product trial used 30 samples and the product trial in large-scale use involved 72 samples with an error rate of $5 \%$. This research also involves research methodology experts and android application experts for product perfection through validation tests. the researcher provides questionnaires and interviews as a data collection tool, then analyzes them using the Aiken`s V formula, if the validity coefficient is less than 0.30 it means the item can be said to be inadequate (invalid) and vice versa if the validity coefficient 0.30 means the item can be said to be adequate (valid)[10, p. 143]. ICC reliability test with criteria >0.5[11]. The analysis continued with the readability test and practicality test. 


\section{Results \& Discussion}

The research begins with a potential and problem analysis, at this stage the potential that supports researchers is the presence of experienced human resources in teaching research methodologies and reliable application developers, besides that Medan State University provides complete facilities to carry out this research, such as a digital library for conducting literature studies, good internet access and other supporting facilities, the obstacles experienced by researchers are that it is still difficult to hold meetings in person to coordinate so that researchers conduct online meetings so that research can continue. in the next stage, the RPS is for adjusting the material in the application and then designing the application, the product that has been designed is then validated by 3 experts.

Experts assess of several aspects, namely material, construction, and language. Experts assess for all aspects of the application that has been developed. The results of the expert assessment were carried out using of a content validity test using the Aiken $\mathrm{V}$ formula which can be seen in Table 1.

Table 1. Test results of application design content validity by experts.

\begin{tabular}{llllll}
\hline Indicator & $\mathrm{V}$ & Criteria & Indicator & $\mathrm{V}$ & Criteria \\
\hline 1 & 0,92 & Valid & 13 & 0,92 & Valid \\
2 & 0,92 & Valid & 14 & 0,17 & Not Valid \\
3 & 0,92 & Valid & 15 & 0,92 & Valid \\
4 & 0,75 & Valid & 16 & 1,00 & Valid \\
5 & 1,00 & Valid & 17 & 1,00 & Valid \\
6 & 0,75 & Valid & 18 & 0,67 & Valid \\
7 & 0,92 & Valid & 19 & 0,92 & Valid \\
8 & 0,83 & Valid & 20 & 0,67 & Valid \\
9 & 0,67 & Valid & 21 & 0,92 & Valid \\
10 & 0,92 & Valid & 22 & 0,83 & Valid \\
11 & 0,92 & Valid & 23 & 0,75 & Valid \\
12 & 0,92 & Valid & 24 & 0,92 & Valid \\
\hline
\end{tabular}

Based on table 1, it can be seen that the content validity test through Aiken V analysis got a value of 0.83 more than 0.3 , so the IRM application was declared content valid based on expert testing. The validity values for each indicator are quite diverse. However, it can be seen that there are indicators that are declared invalid, namely indicator 14 getting a $\mathrm{V}$ value of 0.17. Indicator 14 measures the application in terms of "There are clear instructions on how to use". Experts provide suggestions and recommendations to revise the developed application. Suggestions and input following with indicator 14 which is declared invalid. Experts advise to provide instructions for using the application.

Content validity can describe of the series of attributes that are being studied for assessment by several experts [12]. The content validity of the I-RM application is able to reflect of the completeness of the initial design of application development. Various inputs are needed by researchers in improving and completing based on attributes that are still considered lacking. Based on the results of the study, instructions on how to use it have not been given [13]. Instructions on how to use are quite important attributes for users who are new to using the I-RM application. The analysis continued with the reliability test. 
The ICC Reliability Test is carried out to measure the consistency or suitability of the experts in measuring the application design. The results of the ICC reliability test analysis can be seen in Table 2.

Table 2. Results of expert Test ICC analysis.

\begin{tabular}{cc}
\hline Cronbach's Alpha & Interclass Correlation \\
\hline 0,837 & 0,630 \\
\hline
\end{tabular}

Based on table 2, it is known that the alpha value of 0.837 is greater than 0.5 and the ICC value obtained is 0.630 which is more than 0.5 . The results of the ICC analysis show that the experts have made an appropriate assessment. Experts judge as they should, as other experts do. The results of the ICC reliability test analysis are the basis for stating that the content validity assessment from the expert can be continued by revising the application based on the application, then a small-scale test can be carried out.

The small-scale test involves 30 samples to perform a readability test. Readability test by testing the application to the sample directly to be seen and used and then assessed based on the readability indicators used. The sample provides an assessment using a readability questionnaire. The results of the analysis of the readability test got a score of 159 which was included in the Readability category. The results of the readability test for each indicator can be seen in Table 3 .

Table 3. Results of readability test analysis.

\begin{tabular}{lcc}
\hline \multicolumn{1}{c}{ Indicator } & Yes & No \\
\hline Is the placement of the section title writing clearly legible? & $93 \%$ & $7 \%$ \\
Are the instructions for use clearly legible? & $87 \%$ & $13 \%$ \\
Is the font size on the menu legible? & $87 \%$ & $13 \%$ \\
Is the font size in the module clearly legible? & $77 \%$ & $23 \%$ \\
Is the font size in the data input section of the proposal clearly & $83 \%$ & $17 \%$ \\
legible? & $23 \%$ & $77 \%$ \\
Is the font size in the stored proposal data display clearly legible? & $80 \%$ & $20 \%$ \\
Is each punctuation clearly visible? & & \\
\hline
\end{tabular}

Based on table 3, the analysis of the readability test shows that the application's readability indicators have been able to be read well. However, it can be seen that respondents in the small-scale test gave a fairly low readability rating on the indicator "whether the font size in the display section of the stored proposal data is clearly legible" which received an illegible statement of $77 \%$ of all respondents. Based on the readability test, the application was revised and continued with a large-scale test.

A large-scale test is carried out to test the practicality of the developed application. The large-scale test involved 72 samples to assess the practicality of the developed application. The practicality test will show the respondents' agreement on the ease of use of the application. The practicality test was carried out by distributing a practicality questionnaire consisting of aspects of subjectivity, language, construction, and use. The results of the practicality test in general get a score of $79.8 \%$ which is included in the Practical category. 
The results of the practicality test analysis based on the aspects measured can be seen in Table 4.

Table 4. Results of practicality test analysis.

\begin{tabular}{llc}
\hline \multicolumn{1}{c}{ Aspect } & $\%$ & Criteria \\
\hline Subjectivity & 84 & Very Practical \\
Language & 89 & Very Practical \\
Construction & 66 & Practical enough \\
Use & 83 & Very Practical \\
\hline
\end{tabular}

Based on the results of the analysis of the practicality test, it is known that the application construction gets an assessment in the sufficient category. The construction aspect tests the practicality of the existence of parts in the I-RM Application. The construction of the I-RM application that is still considered lacking is instructions for use that are still unclear, instructions for filling out proposals are still unclear, instructions for correcting data are not clear and the steps stated are not clear enough to guide use.

The use aspect is categorized as very practical. However, respondents experienced problems when replacing smartphone devices, the data that had been stored could not be moved. The data constraint that is only stored on internal devices is a weakness in the development of this I-RM application. Application development by utilizing an account with a cloud database requires the availability of sufficient management, maintenance and costs, so that the system can continue to run properly.

\section{Conclusion}

This study analyzes of the use of I-RM application which is used in learning research methodology. An Android-based I-RM application that can be accessed through the Play Store and installed on devices that support Android services. The I-RM application was developed to make it easier for students to collect the materials found to support the preparation of their final project proposal. Based on the research, the I-RM application entered the Practical criteria used by students. The I-RM application has the advantage that it is easy to use, can store data and compile it into a sequence of final project proposals. However, the I-RM application also has drawbacks, namely the data storage is still in local storage, the data cannot be moved or opened via other devices. Suggestions from the researchers are that further development can be carried out to overcome the shortcomings of the currently developed IRM application and can be tested directly for use in lectures for a longer time.

\section{References}

[1] Purwanto MP, Metodologi Penelitian Kuantitatif untuk Psikologi dan Pendidikan. 2012.

[2] Suhadi. Petunjuk Perangkat Pembelajaran. Surakarta: Universitas Muhammadiyah Surakarta;2007.

[3] Syarofa N. Pengembangan Perangkat Pembelajaran Yang Berorientasi Model Cooperative Learning Tipe Think Pair Share (TPS) Pada Mata Pelajaran PPKn Terhadap Kemampuan Pemecahan Masalah Pada Siswa Kelas V SDN Belitung Selatan 5 Banjarmasin. EduStream J. Pendidik. Dasar. 2020; 4(1):1-20. 
[4] Argaheni NB. Sistematik Review: Dampak Perkuliahan Daring Saat Pandemi Covid-19Terhadap Mahasiswa Indonesia,” PLACENTUM J. Ilm. Kesehat. dan Apl. 2020; 8, (2): 99-108.

[5] Frilia M, Hapizah, Susanti E, Scristia S. Pengembangan Bahan Ajar Materi Prisma Berbasis Android untuk Pembelajaran Berbasis Masalah di Kelas VIII. J. Gantang. 2020; 5(2): 191-201.

[6] Hesti W, Anggraini H, Novianti, Bardadi A. Pengembangan Bahan Ajar Berbasis Android untuk Meningkatkan Kemampuan Pengucapan Pada Mahasiswa. J. Comput. Eng. Syst. Sci. 2018; 3(1): 83-86.

[7] Maulida H, Sinaga P, Susilawati M. Pengembangan Bahan Ajar IPA Terpadu Berbasis Android Berorientasi Keterampilan Berpikir Kritis. J. PETIK. 2019; 5(1):70-76.

[8] Sugiyono. Metode Penelitian Kuantitatif, Kualitatif dan R \& D.Bandung:Alfabeta; 2012.

[9] Sugiyono. Metode dan Prosedur Penelitian. e-Journal, 2014.

[10] Azwar S. Reliabilitas dan validitas. Yogyakarta: Pustaka Pelajar; 2014.

[11] Streiner DL, Norman G. Health measurement scales: A practical guide to their development and use. Oxford: Oxford University Press; 2000.

[12] HA D et al. A psychometric toolbox for testing validity and reliability. J. Nurs. Scholarsh. an Off. Publ. Sigma Theta Tau Int. Honor Soc. Nurs. 2007; 39(2): 155-164.

[13] Ismanto E, Novalia M, Herlandy B. Pemanfaatan Smartphone Android Sebagai Media Pembelajaran Bagi Guru Sma Negeri 2 Kota Pekanbaru. J. Untuk Mu negeRI. 2017; 1(1). 